\title{
A REVISION OF POSTUMIUS (ACARI: PROSTIGMATA: STIGMAEIDAE)
}

\author{
Alexander A. Khaustov ${ }^{1 *}$ and Vladimir V. Abramov ${ }^{2}$ \\ ${ }^{1} \mathrm{X}$-BIO Institute, Tyumen State University, Tyumen, Russia \\ ${ }^{2}$ Independent Researcher, Suvorov, Tula Region, Russia \\ *corresponding author; email: alex1973khaustov@gmail.com
}

ABSTRACT: The genus Postumius Kuznetsov (Acari: Stigmaeidae) is revised. Postumius tectus Kuznetsov and P. gloriosus Kuznetsov are redescribed based on holotypes. P. mikhailovi sp.n. is described from European Russia. A key to the species of the genus Postumius is provided.

KEY WORDS: Acarina, Raphignathoidea, systematics, predatory mites, Russia.

DOI: 10.21684/0132-8077-2021-29-1-115-133

\section{INTRODUCTION}

The mite family Stigmaeidae (Acari: Prostigmata) is the largest in the superfamily Raphignathoidea: it currently includes about 635 species of 33 valid genera (Fan et al. 2016, 2019; Beron 2020; Khaustov 2021). Most stigmaeid mites are freeliving predators of various small arthropods, and some species from the genera Zetzellia and Agistemus are probably the second most important group of plant mite predators (after the Phytoseiidae) (Gerson et al. 2003).

The genus Postumius Kuznetsov, 1977 originally included just one species, P. tectus Kuznetsov, 1977, which was described from forest litter in European Russia (Kuznetsov 1977). Later, Kuznetsov (1978) described the second species, P. gloriosus, from blanket bog litter in a spruce forest, European Russia. Kapaxidi and Papadoulis (1999) reported P. tectus from a pasture in Greece.

During our study of predatory mites, a new species of Postumius was found in the forest litter in European Russia. The type materials of $P$. tectus and $P$. gloriosus were examined for the purposes of comparing them with the new species. The aim of this paper is to redescribe Postumius tectus and $P$. gloriosus based on the holotypes and to describe the new species. A key to the species of Postumius is also provided.

\section{MATERIALS AND METHODS}

Mites were collected from litter using Berlese funnels and mounted in Hoyer's medium. In the description below, the palpal, idiosomal and leg setations follow Grandjean (1939, 1944, 1946). The nomenclature for the prodorsal setae follows Kethley (1990). All measurements for the holotypes and paratypes (in parentheses) are given in micrometres $(\mu \mathrm{m})$. In the descriptions of leg setation, the number of solenidia are given in parenthesis.
Micrographs were taken with a digital camera AxioCam ICc5 via a compound microscope Carl Zeiss AxioImager A2, with a differential interference contrast (DIC) illumination.

\section{SYSTEMATICS}

\section{Family Stigmaeidae Oudemans, 1931}

Genus Postumius Kuznetsov, 1977

Type species: Postumius tectus Kuznetsov, 1977, by original designation.

Diagnosis. Female. Body oval in shape. Chelicerae fused into stylophore. Number of setae on palpal segments: $\operatorname{Tr} 0, \mathrm{Fe} 3$ (d, l', v'), Ge 2 (d, l'), Ti 3 (d, l', l'), Ta 8(1) (fused eupathidia $u l$ ', $u l$ ',, $s u l$, eupathidion $a c m, b a, b p, l p, 1$ solenidion $\omega)$; palptibia with large tibial claw; seta $l$ ' of palptibia modified, short, thick, blunt-tipped and slightly curved. Palptarsus dorsoproximally with lyrifissure. Supracoxal setae of palp (ep) and leg I (el) very short, thick, spine-like. Subcapitulum with two pairs of subcapitular setae $m$ and $n$ and two pairs of proral setae or 1 and or 2 . Dorsal idiosomal setae usually baculiform, with hyaline sheaths. Prodorsal shield with four pairs of setae ( vi, ve, sci, sce) and pair of eyes, postocular bodies absent. Soft cuticle between anterior margin of prodorsal shield and gnathosoma smooth. Hysterosoma dorsally almost completely covered by large central shield bearing setae $c 1, d 1, d 2, e 1, e 2$ and $f$; suranal shield with two pairs of setae $h 1$ and $h 2$ usually located ventrally; humeral shield unusually large, with long anterior, posterior and median projections, fused medially with anterior part of posterior endopodal plates (Fig. 20C, F). Setae $c 2$ situated outside humeral shields on soft cuticle or small platelets. Anterior endopodal plates well developed, with setae $1 a$; posterior endopodal 


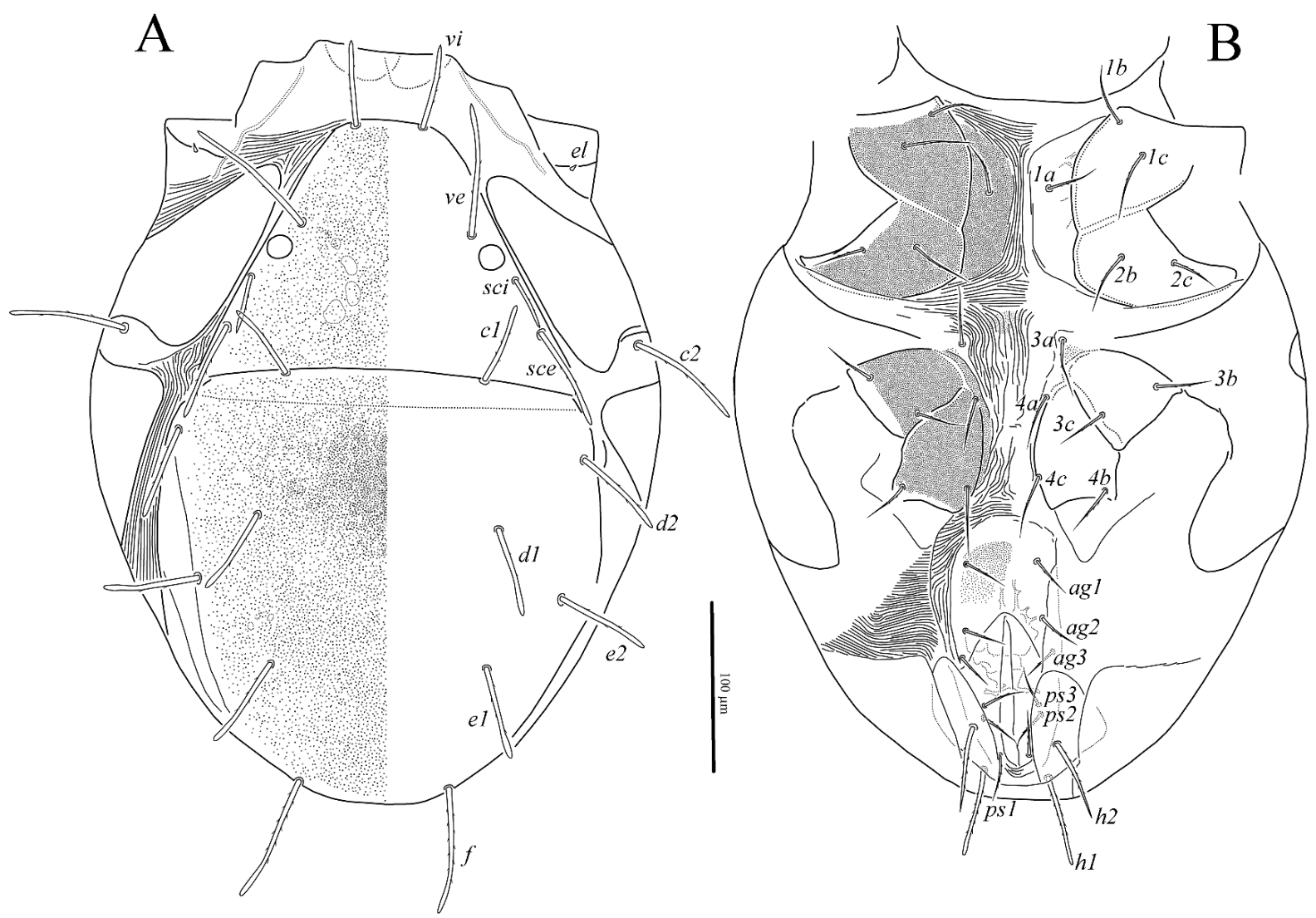

Fig. 1. Postumius tectus Kuznetsov, 1977 female (holotype): A-idiosomal dorsum, B-idiosomal venter.

plates weakly developed, narrow, with setae $3 a$ and $4 a$; coxal fields I-IV with two pairs of setae each. Aggenital plate large, entire, with three pairs of setae; three pairs of pseudanal setae; genital setae absent. Legs I distinctly longer than other legs. Each leg with one pair of well developed claws and three pairs of slightly widened distally empodial raylets. Setation of legs I-IV: leg I: Tr $1\left(v^{\prime}\right)$, Fe 6 (d, l', l', v', v", bv'), Ge 4 (d, l', l', $k)$, Ti 5(2) (d, l', l', v', v", $\varphi, \varphi p)$, Та 13(1) (p', p", $t c^{\prime}, t c^{\prime \prime}, f t^{\prime}$, $\left.f t^{\prime \prime}, u^{\prime}, u^{\prime \prime}, a^{\prime}, a^{\prime \prime}, p l^{\prime}, p l l^{\prime \prime}, v s, \omega\right)$; leg II: Tr $1\left(v^{\prime}\right)$, Fe 5 (d, l', l', v', bv'), Ge 4 (d, l', l’, $k)$, Ti 5(1) $\left(d, l, l l^{\prime \prime}, v^{\prime}, v^{\prime \prime}, \varphi p\right)$, Та 9(1) (p',tc',tc', u', u', $a^{\prime}, a^{\prime \prime}, p l$, $\left.v s, \omega\right)$; leg III: Tr $2\left(v^{\prime}, l^{\prime}\right), \operatorname{Fe} 3\left(d, l^{\prime}\right.$, $\left.e v^{\prime}\right), \operatorname{Ge} 1(d)$, Ti 5(1) (d, l', l’, $\left.v^{\prime}, v^{\prime \prime}, \varphi p\right)$, Ta 7(1) (tc', tc", $\left.u^{\prime}, u^{\prime \prime}, a^{\prime}, a^{\prime \prime}, v s, \omega\right)$; leg IV: Tr $1\left(v^{\prime}\right), \mathrm{Fe}$ $2\left(d, e v^{\prime}\right)$, Ge $1(d)$, Ti 5(1) (d, l', l’, $\left.v^{\prime}, v^{\prime \prime}, \varphi p\right)$, Ta 7(1) (tc', tc', $\left.u^{\prime}, u^{\prime \prime}, a^{\prime}, a^{\prime \prime}, v s, \omega\right)$.

Male and immatures unknown.

Species included. The genus Postumius includes three species: P. tectus Kuznetsov, 1977, P. gloriosus Kuznetsov, 1978 and P. mikhailovi sp.n.

Distribution and habitats. All species are described from forest litter and soil from European Russia. Postumius tectus has also been recorded from Greece (Kapaxidi and Papadoulis 1999).

\section{Postumius tectus Kuznetsov, 1977}

Postumius tectus Kuznetsov 1977: 301, Fig. 2, I.

(Figs. 1-7)

Redescription. Female. Length of idiosoma 435, width 335 .

Idiosomal dorsum (Figs. 1A, 5, 6A, 7C). Prodorsal and central hysterosomal shields with tiny puncta (Fig. 7C), without dimples; puncta in central part of central hysterosomal shield located more densely than in other parts; humeral shields smooth. Dorsal hysterosomal setae sparsely barbed, with hyaline sheaths (Fig. 5); setae $h 2$ blunt-tipped, without hyaline sheaths. Anterior projection of humeral shield long, reaching beyond bases of setae ve. Humeral shields with deep, almost oval lateral incisions; setae $c 2$ located inside incisions on soft cuticle (Fig. 7E). Length of dorsal setae: $v i$ 51, ve 83, sci 35, sce 61, c1 48, c2 70, d1 54, d2 57, e1 55, e2 57,f76, h1 53, h2 49.

Idiosomal venter (Figs. 1B, 6B, 7D-F). All ventral plates densely punctate; anterior endopodal and aggenital plates with weak subcuticular reticulation. Cuticle between bases of setae $3 a$ with some tiny puncta; cuticle between coxal fields IV sometimes with small platelet (Fig. 7F); striae 


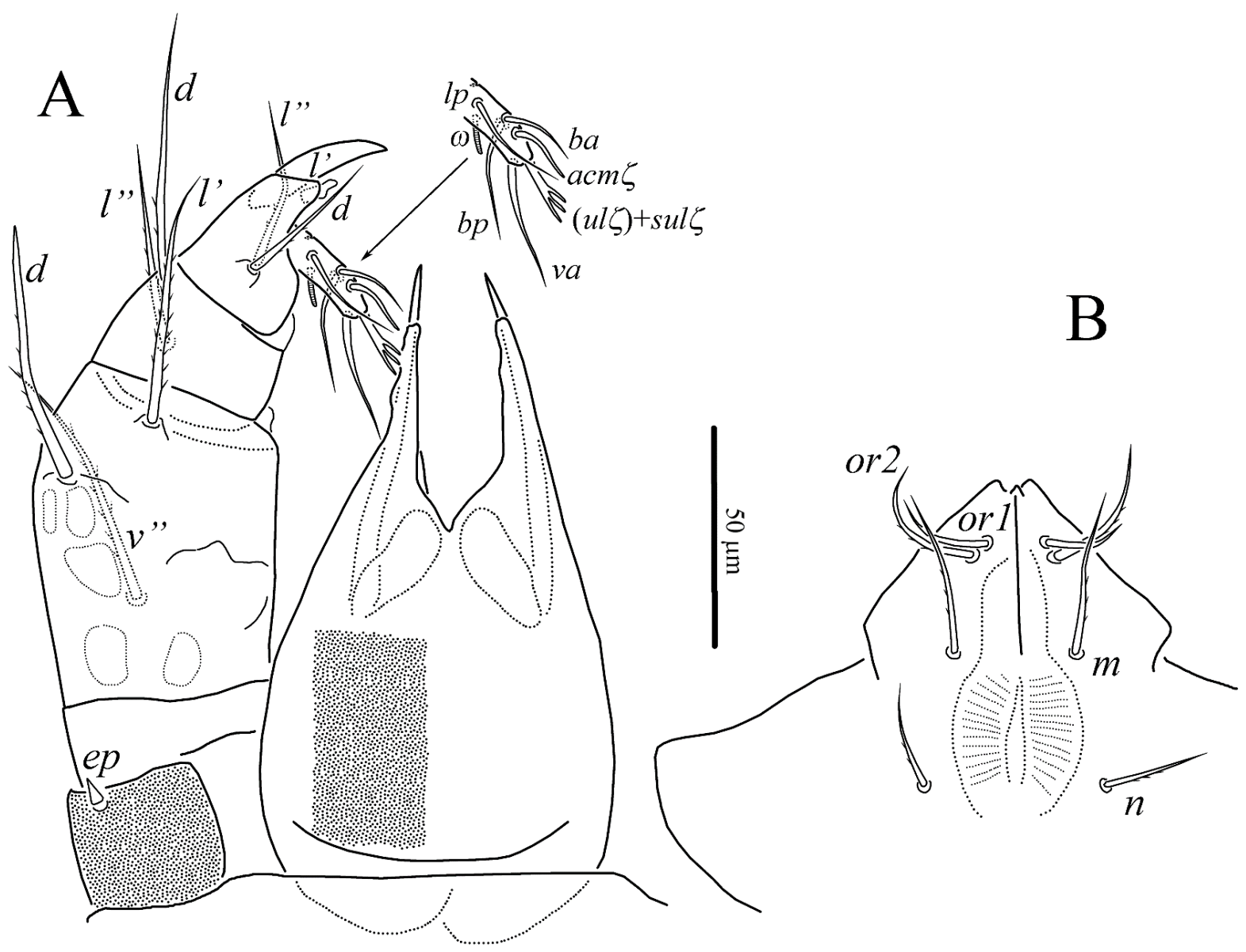

Fig. 2. Postumius tectus Kuznetsov, 1977 female (holotype): A—gnathosoma, dorsal aspect; B—subcapitulum.

between coxal fields II and anterior margin of humeral shield hardly discernible. All ventral setae weakly barbed and pointed. Length of ventral setae: $1 a$ 34, $1 b 35,1 c 42,2 b 38,2 c 33,3 a 35,3 b$ 31, 3c 30, 4a 33, 4b 30, 4c 40, ag1 28, ag2 25, ag3 25, ps1 30, ps2 29, ps3 28.

Gnathosoma (Figs. 2, 7A, B). Chelicerae and subcapitulum densely punctate (Figs. 7A, B). Seta $d$ of palpfemur blunt-tipped and barbed; other setae on femur, genu and tibia (except modified $l$ ' of tibia) pointed and barbed; all tarsal setae smooth. All subcapitular setae pointed; setae or 1 smooth, other subcapitular setae weakly barbed. Length of subcapitular setae: $m 38, n 24$, or $_{1} 23$, $\mathrm{or}_{2} 32$; length of palp 155; length of cheliceral stylet 80 ; solenidion $\omega 9$.

Legs (Figs. 3, 4). Leg segments without distinct reticulation. Lengths of legs: I 320, II 230, III 230, IV 280. Leg I (Fig. 3A). Setae $d$ of tibia and $(p),(t c),(f t)$ of tarsus smooth, blunt-tipped eupathid-like; setae $d$ of femur and genu with rounded and flattened tip; seta $k$ of genu smooth and weakly blunt-tipped, other leg setae pointed and barbed. Seta $d$ of genu subequal with seta $k$
56. Solenidion $\omega 27$ finger-shaped with slightly attenuate tip; solenidion $\varphi 11$ baculiform, $\varphi p 30$ attenuate. Leg II (Fig. 3B). Setae $d$ of tibia, $p$ ' and $t c$ ' of tarsus smooth, blunt-tipped eupathid-like. Solenidion $\omega 20$ finger-shaped with slightly attenuate tip; solenidion $\varphi p 26$ attenuate. Seta $k 8$ short, more than four times shorter than seta $d$ of genu. Setae $d$ of femur and genu barbed, with rounded and flattened tip; seta $l$ " of genu barbed and blunt-tipped; seta $k$ of genu smooth and blunttipped, other leg setae pointed and barbed. Leg III (Fig. 4A). Solenidion $\omega 9$ baculiform; solenidion $\varphi p 25$ attenuate. Setae $d$ of femur and genu with rounded and flattened tip; seta $d$ of tibia blunttipped, other leg setae pointed; all leg setae barbed; Leg IV (Fig. 4B). Solenidion $\omega 5$ weakly clavate; solenidion $\varphi p 30$ attenuate. Setae $d$ of femur, genu and tibia with rounded and flattened tip; seta $l$ ' of tibia blunt-tipped, other leg setae pointed; all leg setae barbed.

Material examined. Female holotype and one female paratype, slide № 911/6, Russia, vicinities of the City of Voronezh, in litter under spruce, 30 April 1972, coll. N.N. Kuznetsov. 


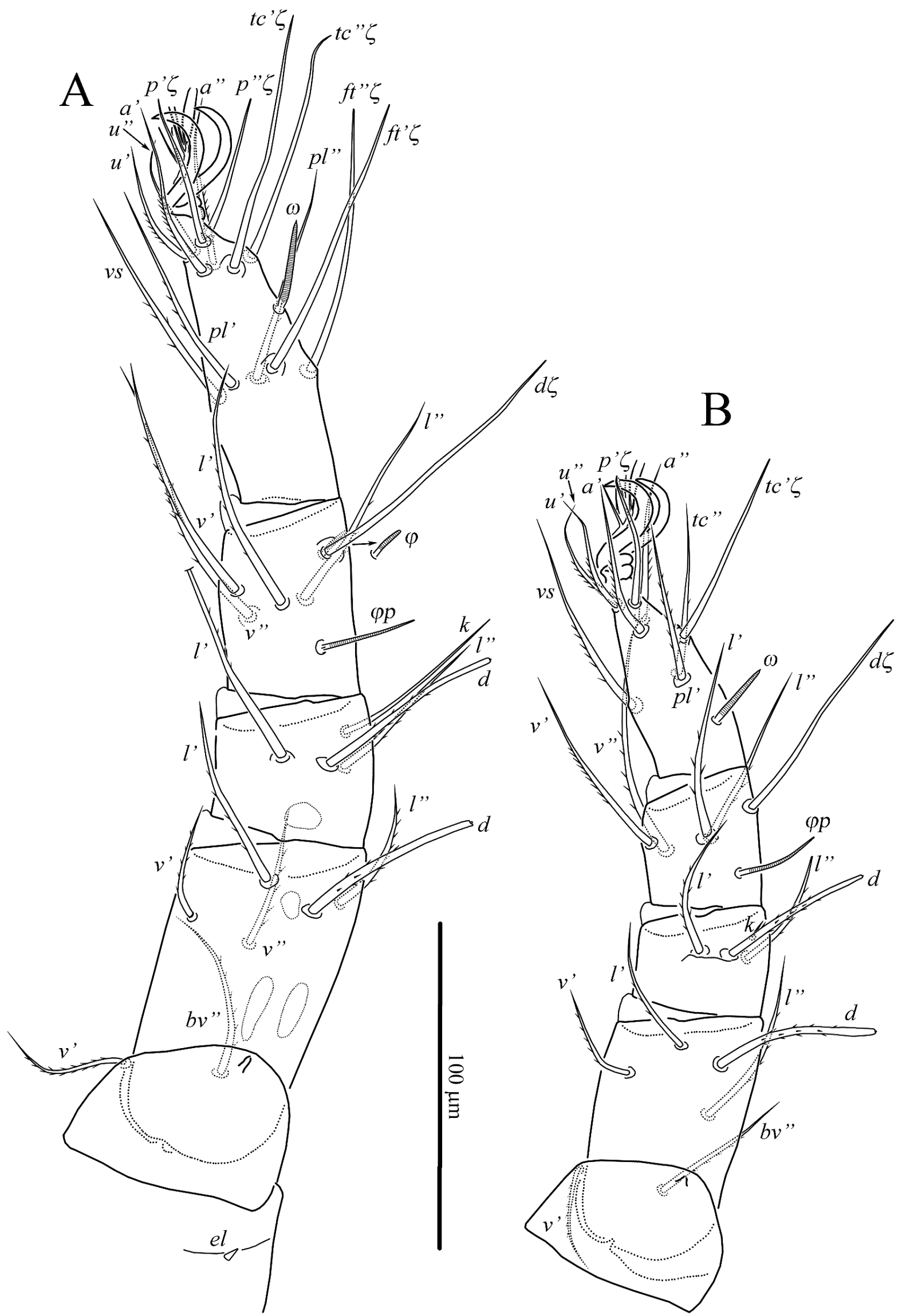

Fig. 3. Postumius tectus Kuznetsov, 1977 female (holotype): A—right leg I, dorsal aspect; B—right leg II, dorsal aspect. 

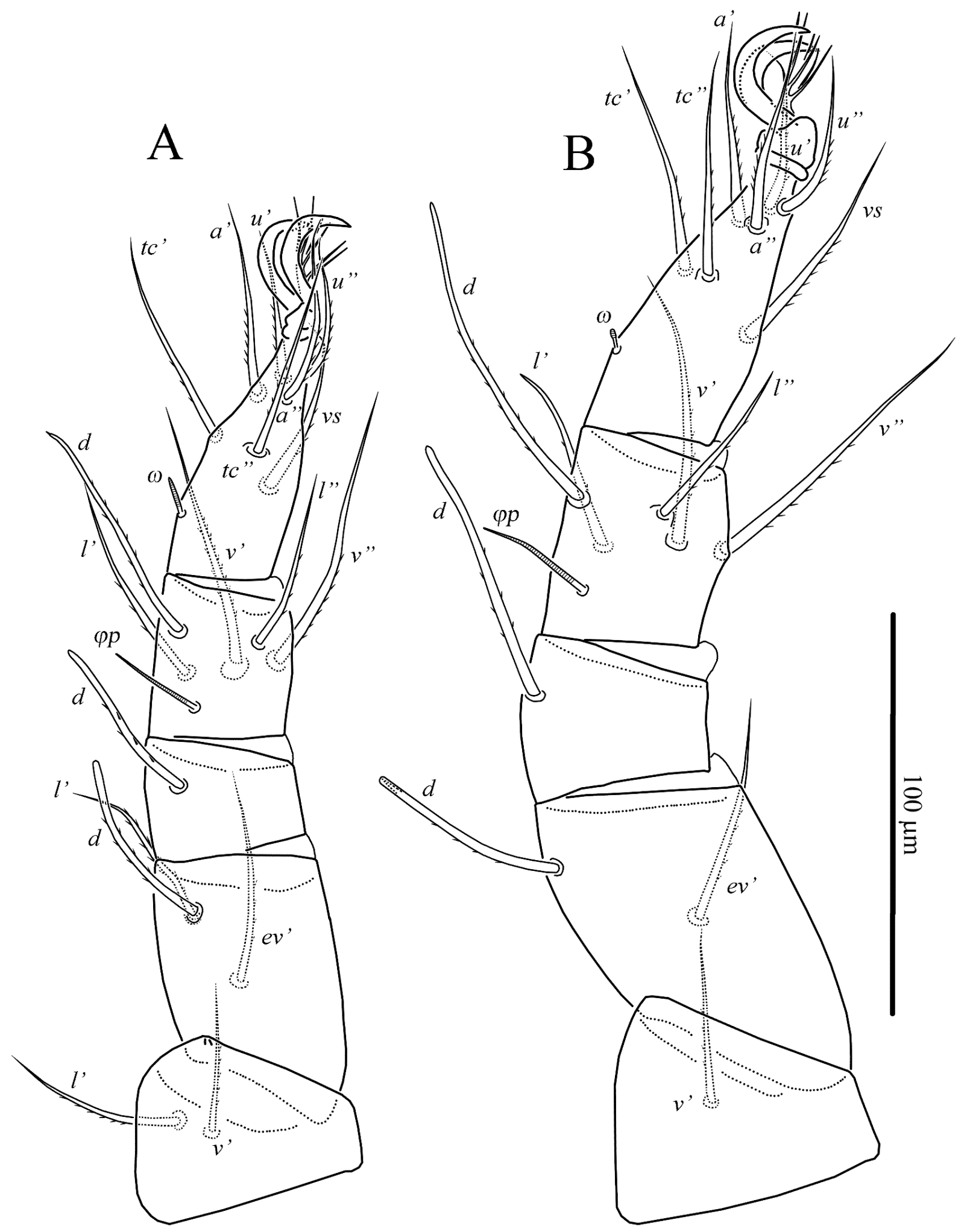

Fig. 4. Postumius tectus Kuznetsov, 1977 female (holotype): A—right leg III, dorsal aspect; B—right leg IV, dorsal aspect.

Type deposition. The type material is deposited in the mite collection of the Tyumen State University Museum of Zoology, Tyumen, Russia.
Postumius gloriosus Kuznetsov, 1978

Postumius gloriosus Kuznetsov 1978: 51, Fig. 2.

(Figs. 8-13) 

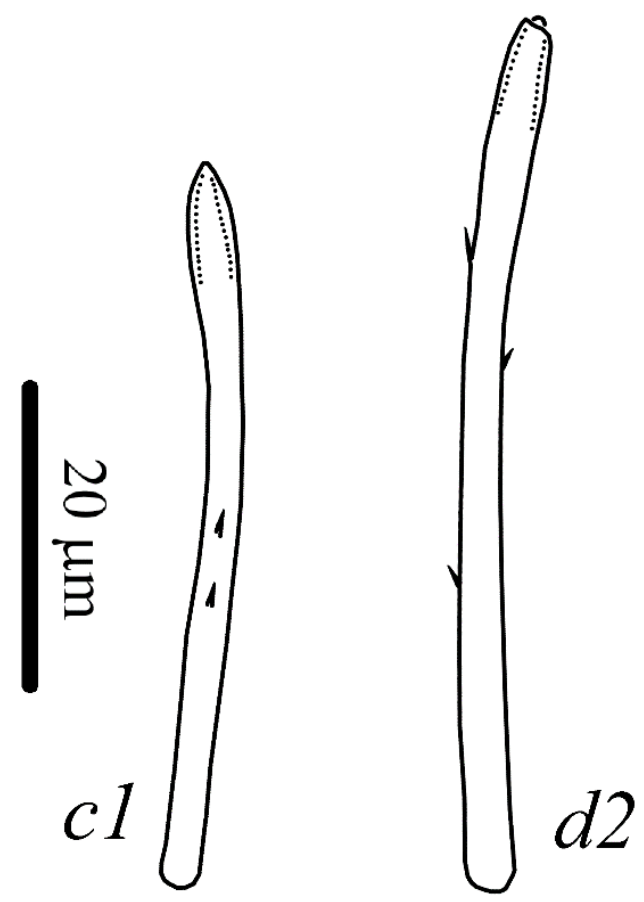

Fig. 5. Postumius tectus Kuznetsov, 1977 female (holotype): dorsal idiosomal setae.

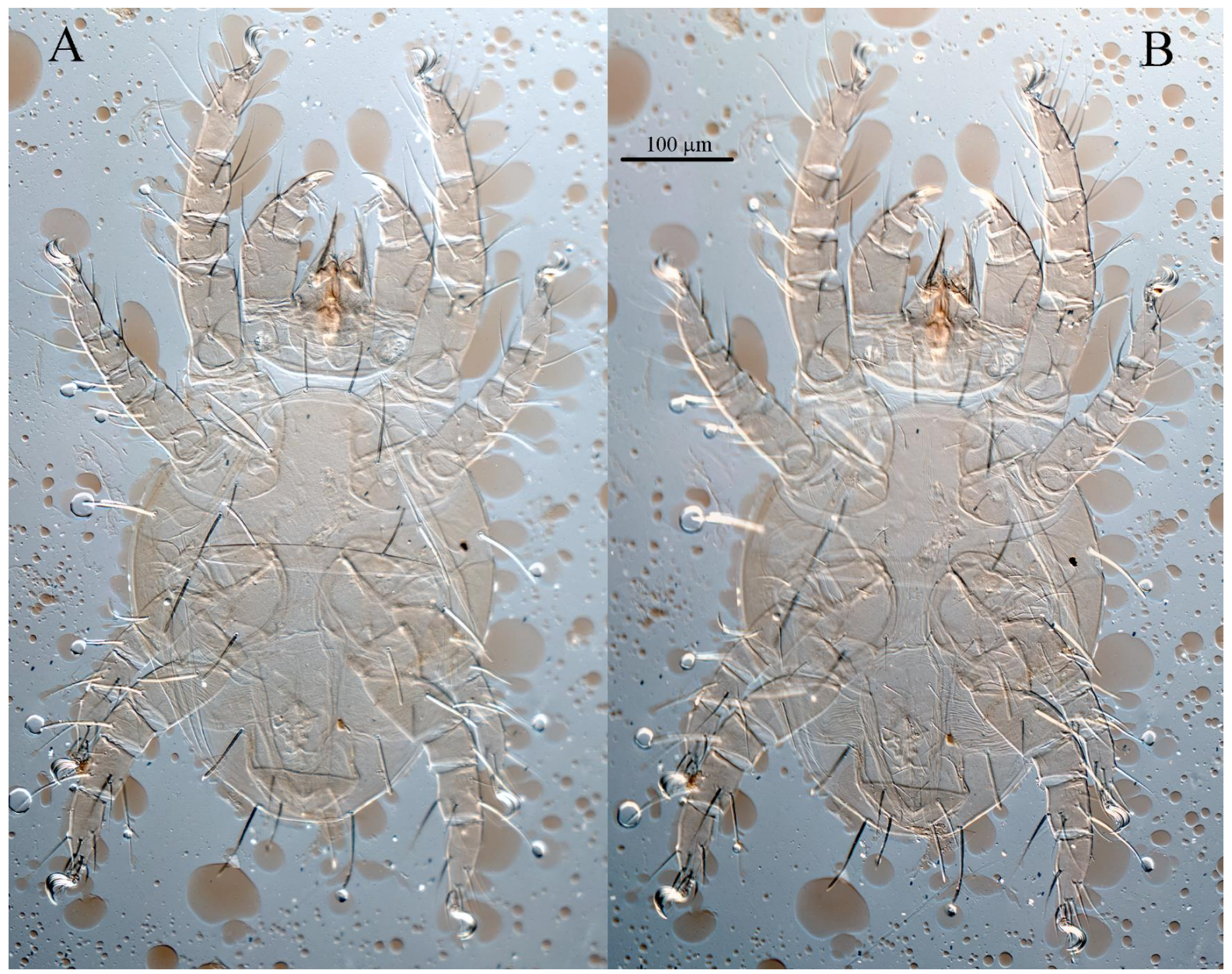

Fig. 6. DIC micrographs of Postumius tectus Kuznetsov, 1977 female (holotype): A—general view dorsally, B—general view ventrally. 


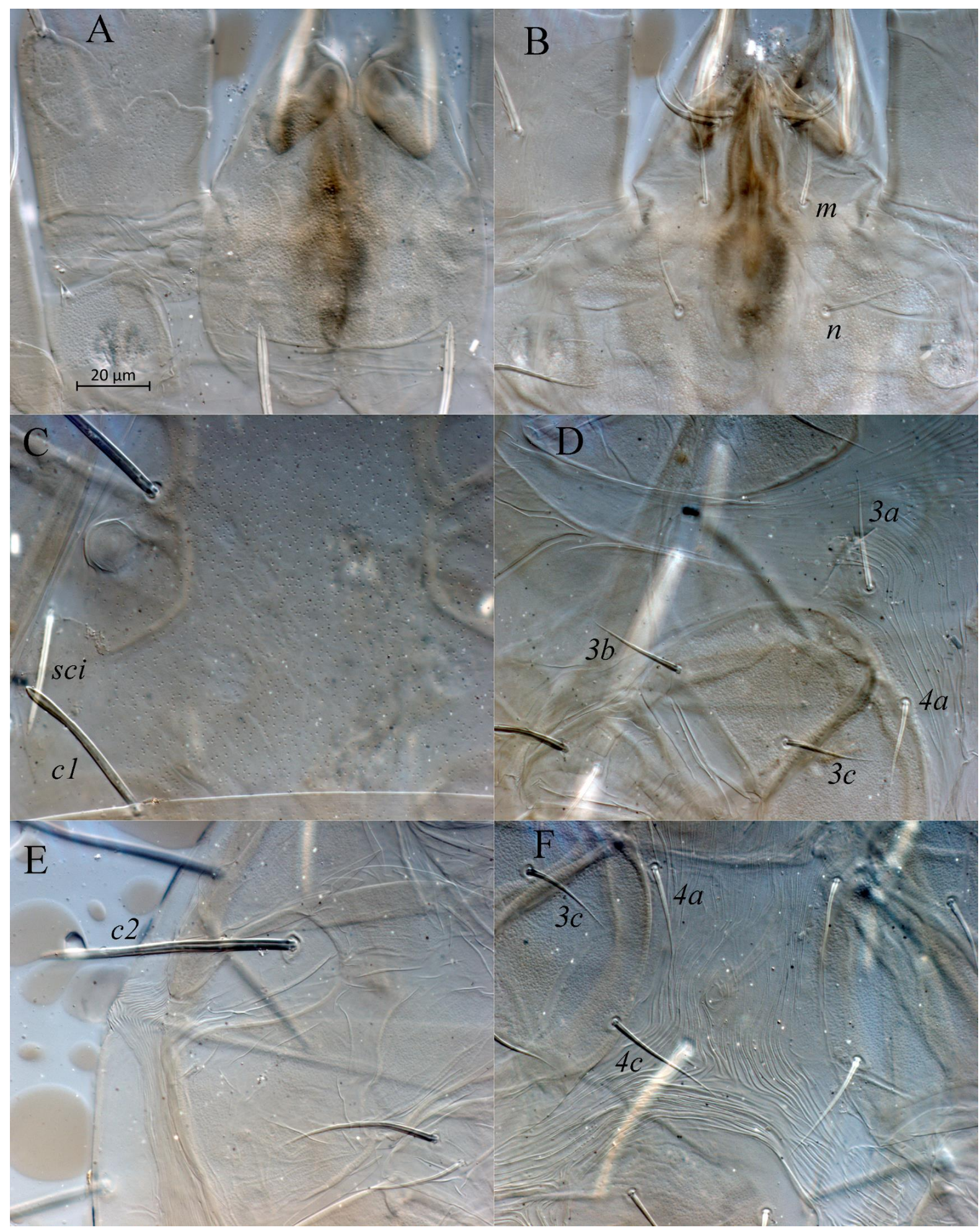

Fig. 7. DIC micrographs of Postumius tectus Kuznetsov, 1977 female (A-D - holotype; E, F-paratype): A—gnathosoma, dorsal aspect; B-subcapitulum; C-prodorsal shield; D—metapodosomal venter showing fusion of endopodal plate of legs III and IV with humeral plate; E-humeral plate and seta $c 2 ; \mathrm{F}$ - striation between coxal fields IV.

Redescription. Female. Length of idiosoma 360 , width 290.

Idiosomal dorsum (Figs. 8A, 12A, 13C). Prodorsal and central hysterosomal shields with hardly discernible, very small puncta (Fig. 13C), without dimples; humeral shields smooth. Dorsal hysterosomal setae sparsely barbed, blunt-tipped, with hardly discernible hyaline sheaths; setae $c 2$ and $h 2$ pointed and barbed. Anterior projection of humeral shield short, reaching beyond bases of 


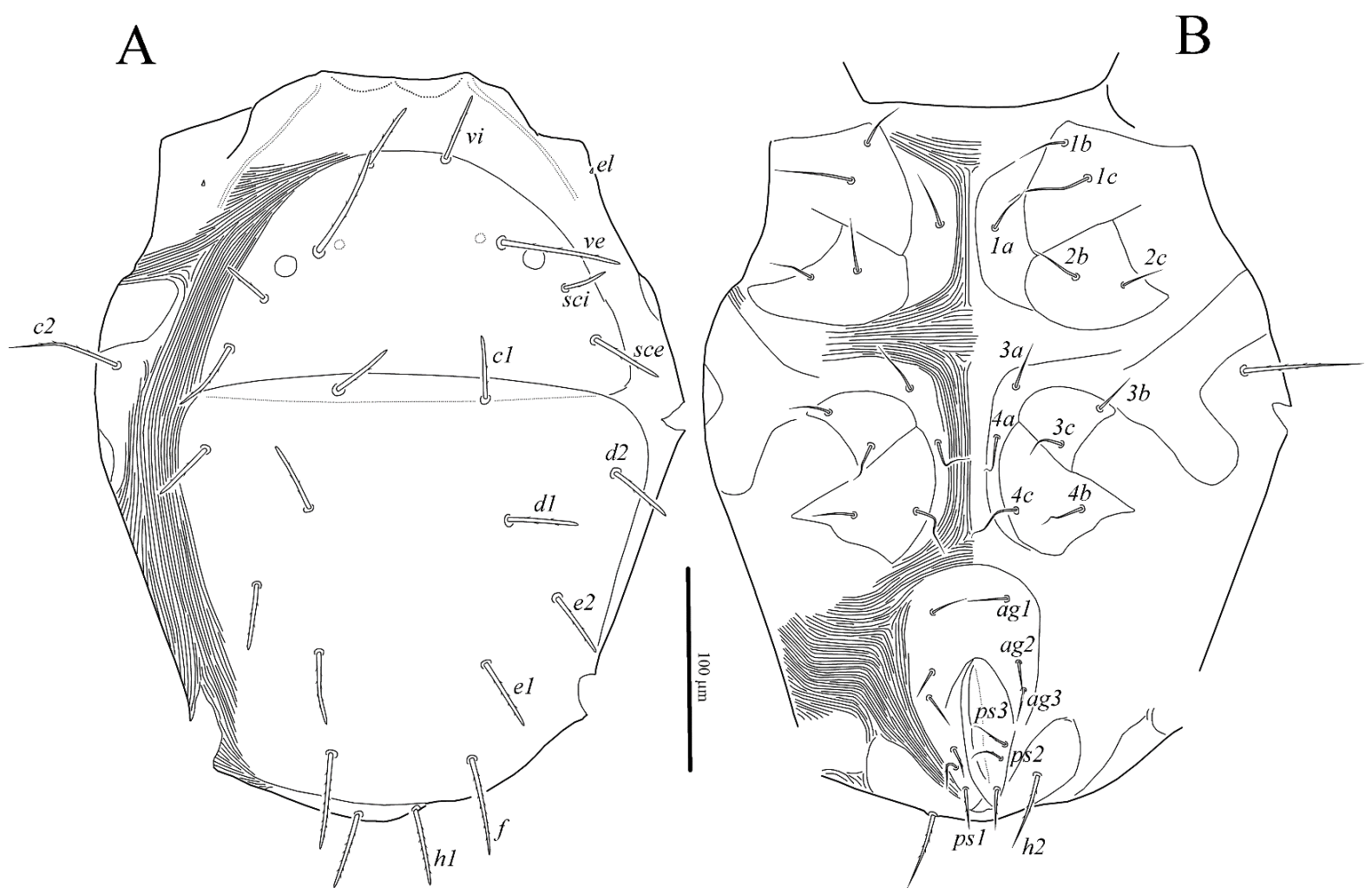

Fig. 8. Postumius gloriosus Kuznetsov, 1978 female (holotype): A-idiosomal dorsum, B-idiosomal venter.

setae $s c i$. Humeral shields with deep lateral depression; setae $c 2$ located inside depression on soft cuticle (Fig. 13C, D). Length of dorsal setae: vi 34, ve 59, sci 22, sce 37, c1 32, c2 55, d1 35, d2 33, e1 $37, e 234, f 48, h 137, h 236$.

Idiosomal venter (Figs. 8B, 12B, 13D-F). Microsculpture of ventral plates not clearly discernible. Cuticle between coxal fields III and IV without platelet or puncta (Fig. 13F); striae between coxal fields II and anterior margin of humeral shield hardly discernible. Setae $p s 1-p s 3$ weakly barbed, other ventral setae smooth; all ventral setae pointed. Length of ventral setae: $1 a 26,1 b 26,1 c 42,2 b$ 29, $2 c 23,3 a 26,3 b 21,3 c 20,4 a 21,4 b 20,4 c 28$, ag1 20, ag2 18, ag3 19, ps1 21, ps2 20, ps3 16.

Gnathosoma (Figs. 9, 13A, B). Chelicerae and subcapitulum densely punctate (Fig. 13A, B). All setae on femur, genu and tibia (except modified $l$ ' of tibia) pointed and barbed; seta $v a$ of tarsus weakly barbed; other tarsal setae smooth. All subcapitular setae pointed; setae or 1 smooth, other subcapitular setae weakly barbed. Length of subcapitular setae: $m 33, n 22$, or 1 17, or 22 ; length of palp 140; length of cheliceral stylet 72 ; solenidion $\omega 8$.

Legs (Figs. 10, 11). Leg segments without distinct reticulation. Lengths of legs: I 265, II 205, III 185, IV 240. Leg I (Fig. 10A). Setae $d$ of tibia and $(p),(t c),(f t)$ of tarsus smooth, blunt-tipped eupathidlike; seta $k$ of genu smooth and weakly blunt-tipped, other leg setae pointed and barbed. Seta $d$ of genu subequal with seta $k 56$. Solenidion $\omega 25$ fingershaped with rounded tip; solenidion $\varphi 12$ baculiform, $\varphi p 31$ attenuate. Leg II (Fig. 10B). Setae $d$ of tibia, $p$ ' and $t c^{\prime}$ of tarsus smooth, blunt-tipped eupathidlike; seta $k$ of genu smooth and blunt-tipped, other leg setae pointed and barbed. Solenidion $\omega 17$ fingershaped with rounded tip; solenidion $\varphi p 25$ attenuate. Seta $k 8$ short, more than four times shorter than setae $d$ of genu. Leg III (Fig. 11A). Solenidion $\omega 10$ baculiform; solenidion $\varphi p 20$ attenuate. All leg setae pointed and barbed. Leg IV (Fig. 11B). Solenidion $\omega 5$ baculiform; solenidion $\varphi p 29$ attenuate. All leg setae pointed and barbed.

Material examined. Female holotype, slide № 186-4, Russia, Yaroslavl Region, vicinities of Borok town, in blanket bog litter in spruce forest, 22 April 1975, coll. N.N. Kuznetsov.

Type deposition. The type material is deposited in the mite collection of the Tyumen State University Museum of Zoology, Tyumen, Russia.

\section{Postumius mikhailovi sp.n.}

(Figs. 14-20)

Description. Female. Length of idiosoma 420 (400-445), width 325 (320-350). 


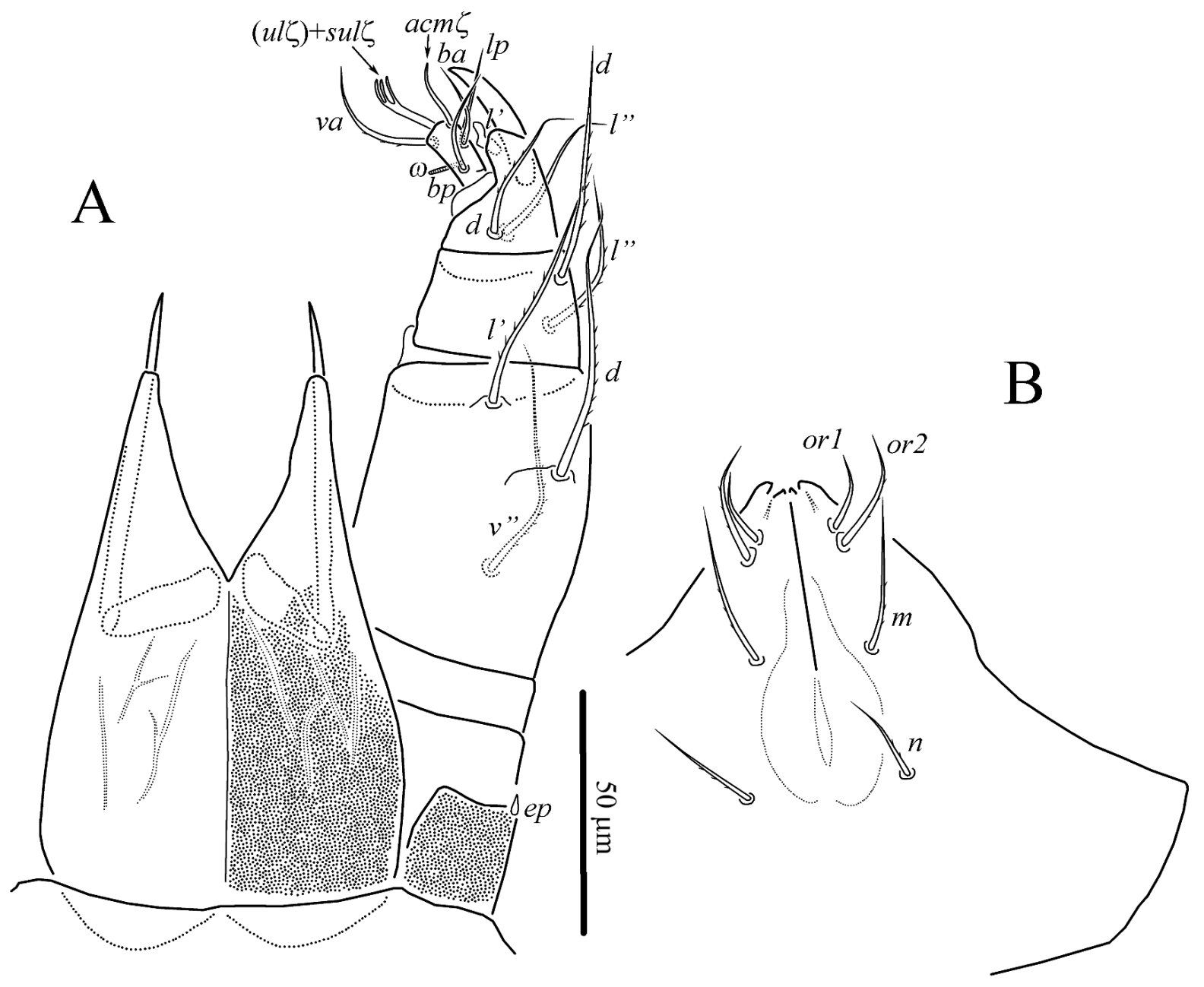

Fig. 9. Postumius gloriosus Kuznetsov, 1978 female (holotype): A—gnathosoma, dorsal aspect; B—subcapitulum.

Idiosomal dorsum (Figs. 14A, 18, 19A, 20A, D, F). Prodorsal and central hysterosomal shields with small puncta and distinct small dimples (Fig. 20A), humeral shields smooth. Dorsal hysterosomal setae sparsely barbed, usually with hyaline sheaths (Fig. 18); setae $h 2$ pointed and barbed. Anterior projection of humeral shield long, reaching beyond bases of setae ve. Humeral shields with lateral depression; setae $c 2$ located inside depression on separate platelet (Fig. 20F). Central hysterosomal shield with cupules ip located anterolaterad bases of setae $f$ and clearly visible only in lateral view (Fig. 20D); suranal shield with cupules ih located laterad bases of setae $h 2$. Length of dorsal setae: vi 51 (50-59), ve 68 (68-73), sci 45 (44-48), sce 58 (55-59), c1 44 (44-48), c2 71 (69-73), d1 48 (46-49), d2 55 (53-56), el 52 (51-54), e2 53 (51-54), f 75 (73-78), h1 47 (4753), h2 48 (47-52).

Idiosomal venter (Figs. 14B, 19B, 20B, C). All ventral plates densely punctate; anterior endopodal and aggenital plates with weak subcuticular reticulation. Cuticle between coxal fields IV with small area with puncta (Fig. 20B); striae between coxal fields II and anterior margin of humeral shield hardly discernible. All ventral setae weakly barbed and pointed, in some specimens most of ventral setae smooth. Female holotype without left aggenital seta ag1. Length of ventral setae: $1 a 37(36-41), 1 b 35$ (33-37), 1c 46 (44-50), $2 b 36$ (35-38), 2c 36 (3338), $3 a 37$ (33-38), $3 b 30$ (28-33), 3c 31 (30-34), $4 a 30$ (30-35), 4b 32 (30-34), 4c 33 (32-37), agl 27 (25-29), ag2 24 (23-26), ag3 28 (26-29), ps 128 (26-30), ps2 29 (28-31), ps3 27 (26-28).

Gnathosoma (Figs. 15, 20E). Chelicerae and subcapitulum densely punctate (Fig. 20E). Stylophore with one pair of short and blunt dorsodistad projections. All setae on femur, genu and tibia (except modified $l$ ' of tibia) pointed and barbed; seta $v a$ of tarsus weakly barbed; other tarsal setae smooth. All subcapitular setae pointed; setae or 1 smooth, other subcapitular setae weakly barbed. 


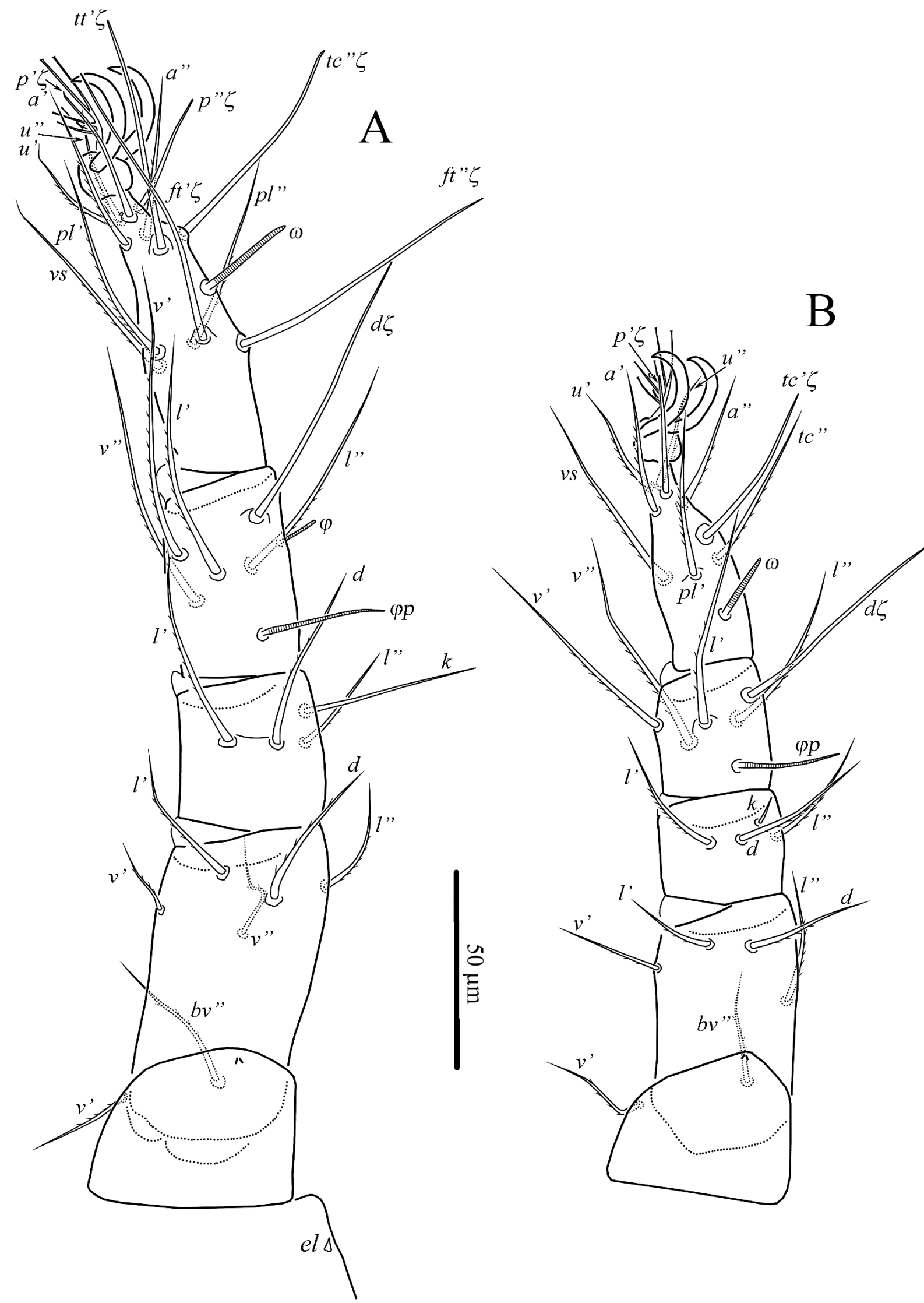

Fig. 10. Postumius gloriosus Kuznetsov, 1978 female (holotype): A—right leg I, dorsal aspect; B-right leg II, dorsal aspect. 

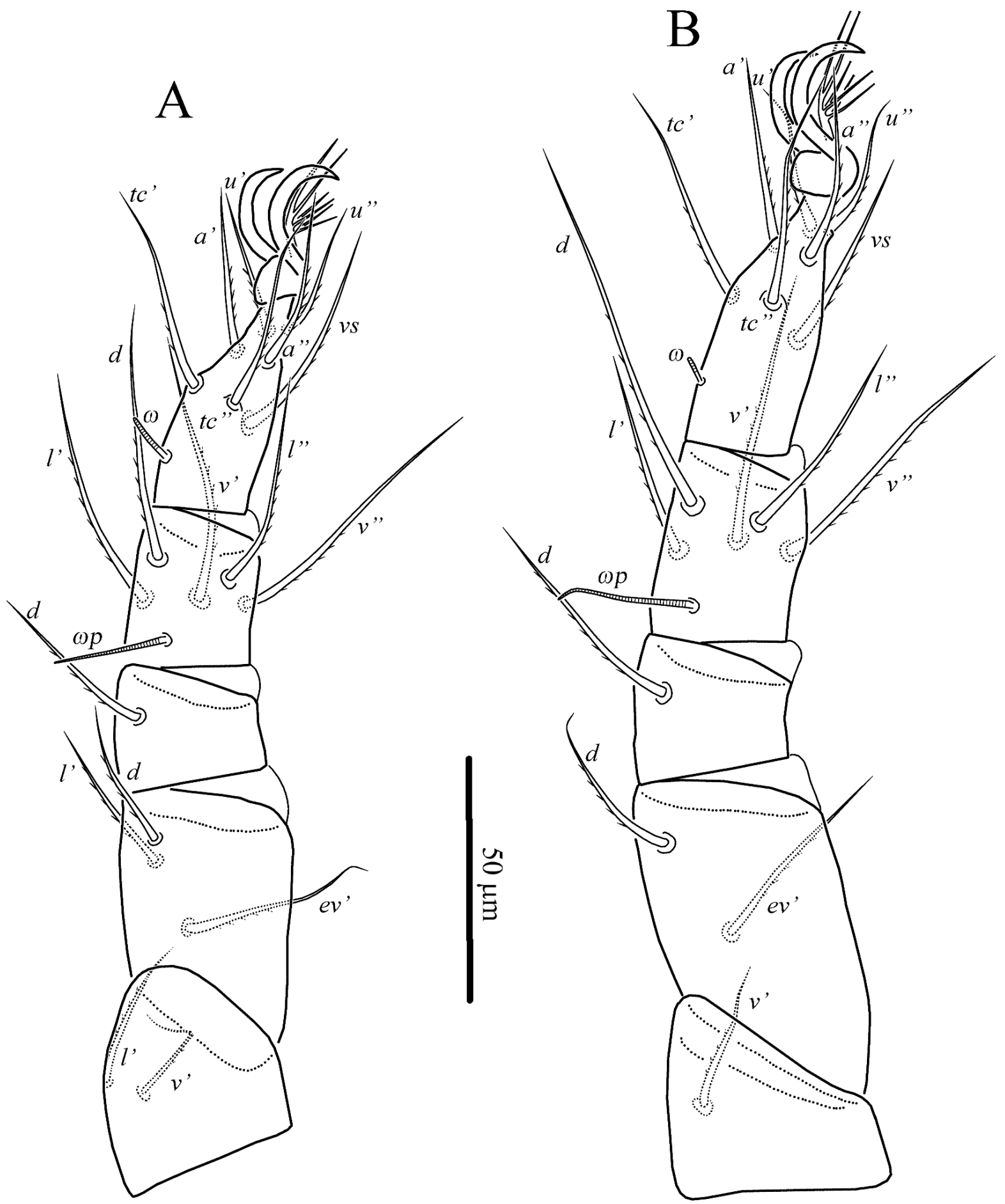

Fig. 11. Postumius gloriosus Kuznetsov, 1978 female (holotype): A—right leg III, dorsal aspect; B—right leg IV, dorsal aspect.

Length of subcapitular setae: $m 43$ (42-46), $n 26$ (25-28), or 25 (23-26), or 230 (29-33); length of palp 160 (160-175); length of cheliceral stylet 79 (78-85); solenidion $\omega 14$ (12-15).

Legs (Figs. 16, 17). Leg segments without distinct reticulation. Lengths of legs: I 325 (325-345), II 235 (235-260), III 230 (230-240), IV 260 (260270). Leg I (Fig. 16A). Setae $d$ of tibia and ( $p),(t c)$,
( $f t$ ) of tarsus smooth, blunt-tipped eupathid-like; setae $d$ of femur and genu with rounded and flattened tip; seta $k$ of genu smooth and weakly blunt-tipped, other leg setae pointed and barbed. Seta $d$ of genu subequal to seta $k 53(52-56)$. Solenidion $\omega 23$ (23-27) finger-shaped with slightly attenuate tip; solenidion $\varphi 15$ (11-15) baculiform, $\varphi p 29$ (27-30) attenuate. Leg II (Fig. 16B). Setae $d$ of tibia, $p$ ' and 


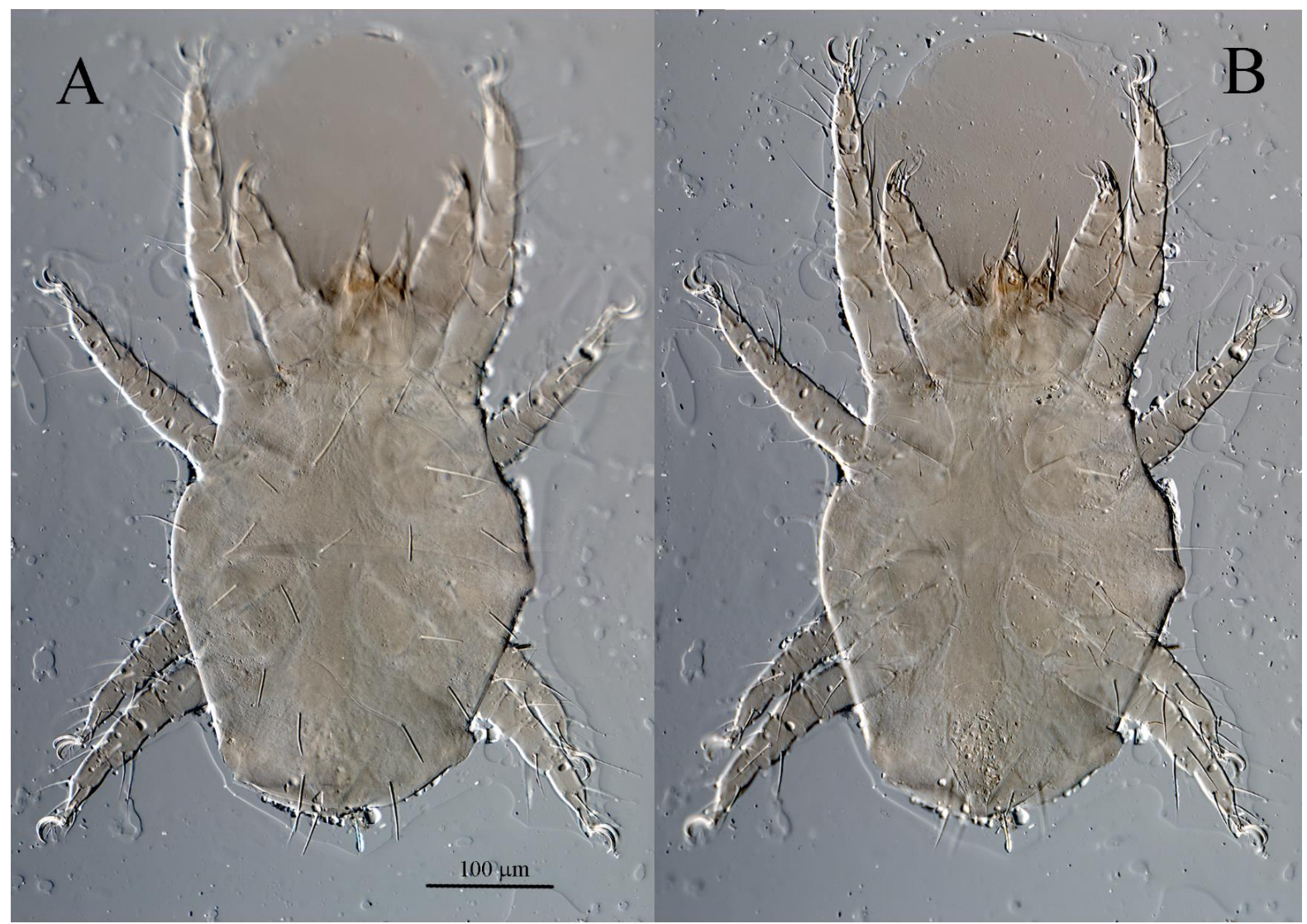

Fig. 12. DIC micrographs of Postumius gloriosus Kuznetsov, 1978 female (holotype): A-general view dorsally, B-general view ventrally.

tc' of tarsus smooth, blunt-tipped eupathid-like; seta $k$ of genu smooth and blunt-tipped; setae $d$ of femur and genu barbed, with rounded and flattened tip, other leg setae pointed and barbed. Solenidion $\omega 20$ (19-22) finger-shaped with slightly attenuate tip; solenidion $\varphi p 26$ (24-28) attenuate. Seta $k 12$ (1013) short, about four times shorter than setae $d$ of genu. Leg III (Fig. 17A). Solenidion $\omega 11$ (11-13) baculiform; solenidion $\varphi p 20$ (19-21) attenuate. Setae $d$ of femur and genu with rounded and flattened tip; seta $d$ of tibia blunt-tipped, other leg setae pointed; all leg setae barbed. Leg IV (Fig. 17B). Solenidion $\omega 6$ (5-6) baculiform; solenidion $\varphi p 23$ (22-24) attenuate. Setae $d$ of femur and genu with rounded and flattened tip; seta $d$ of tibia blunt-tipped, other leg setae pointed; all leg setae barbed.

Type material. Female holotype, slide № ZISP T-St-004, Russia, Tula Region, vicinities of the Town of Suvorov, in litter under oak, 24 April 2019, coll. V.V. Abramov; paratypes: 10 females, same data.

Type deposition. The holotype and two paratypes are deposited in the mite collection of the Zoological Institute of RAS, St. Petersburg, Russia; other paratypes are deposited in the collection of the Tyumen State University Museum of Zoology, Tyumen, Russia.

Differential diagnosis. The new species is most similar to $P$. tectus in having setae $c 2$ and setae $d$ on femora and genua of legs I-IV blunttipped; the long anterior projection of humeral shield reaching beyond the bases of setae ve. The new species differs from P. tectus in having not so deep lateral depression on humeral shields (vs. very deep, almost oval incision in P. tectus); setae $c 2$ located on a separate platelet (vs. setae $c 2$ located on soft cuticle in $P$. tectus); and the presence of small dimples on dorsal idiosomal shields (vs. dorsal idiosomal shields without dimples, only with tiny puncta in P. tectus).

Etymology. The new species is named after a well-known Russian arachnologist Dr. Kirill Mikhailov, who was one of the founders of Acarina, the Russian Journal of Acarology.

\section{Key to the species of the genus Postumius (females)}

1. Setae $c 2$ and setae $d$ on femora and genua of legs I-IV clearly blunt-tipped; anterior projection of 


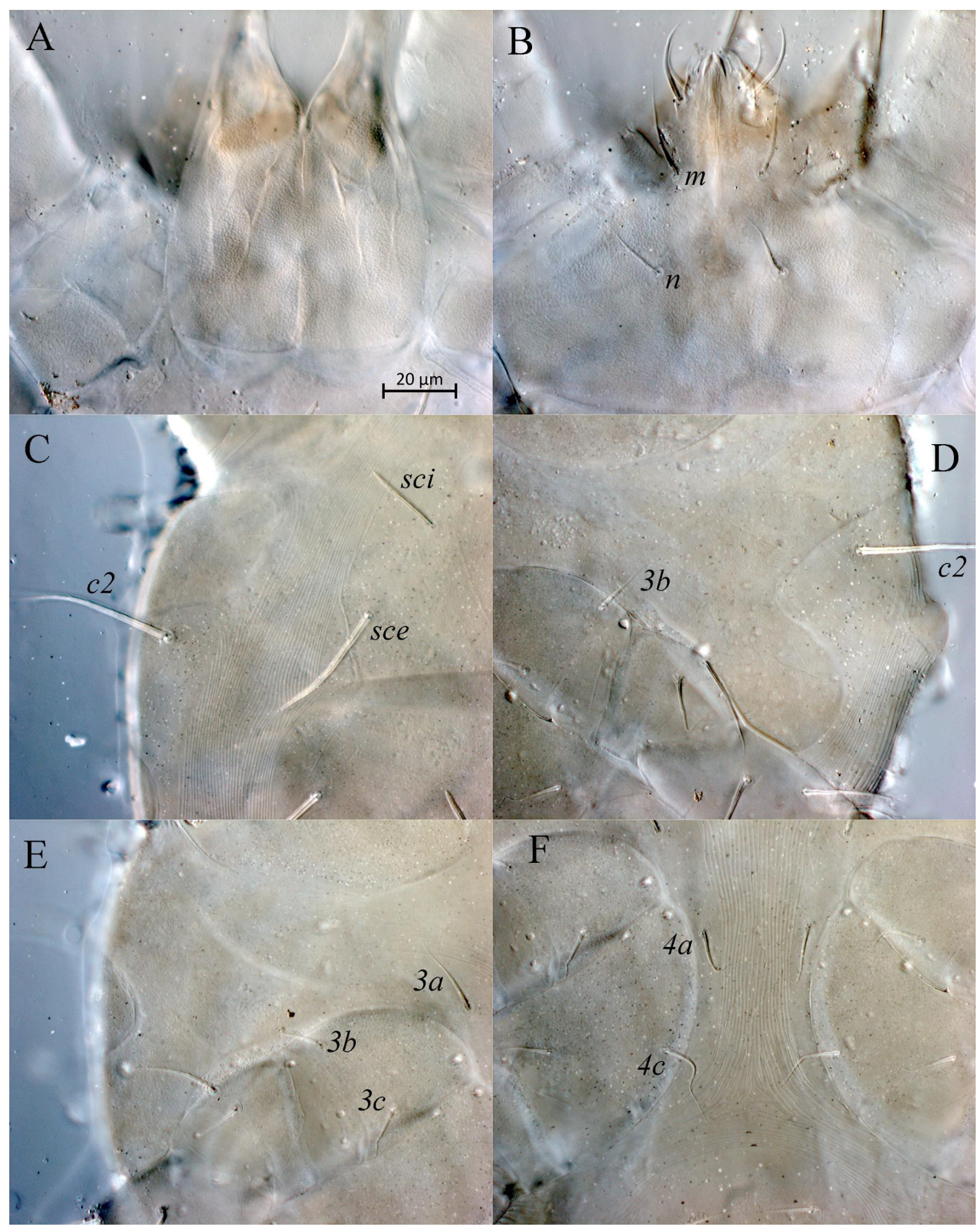

Fig. 13. DIC micrographs of Postumius gloriosus Kuznetsov, 1978 female (holotype): A—gnathosoma, dorsal aspect; $\mathrm{B}$-subcapitulum; C-left part of prodorsum; D—right humeral plate and seta $c 2$; E-metapodosomal venter showing fusion of endopodal plate of legs III and IV with humeral plate; F-striation between coxal fields IV.

humeral shields long, reaching beyond bases of setae ve ...2

- Setae $c 2$ and setae $d$ on femora and genua of legs I-IV pointed; anterior projection of humeral shields shorter, reaching beyond bases of setae sci......

P. gloriosus

2. Setae $c 2$ located on smooth cuticle; humeral shields with very deep, almost oval incision 


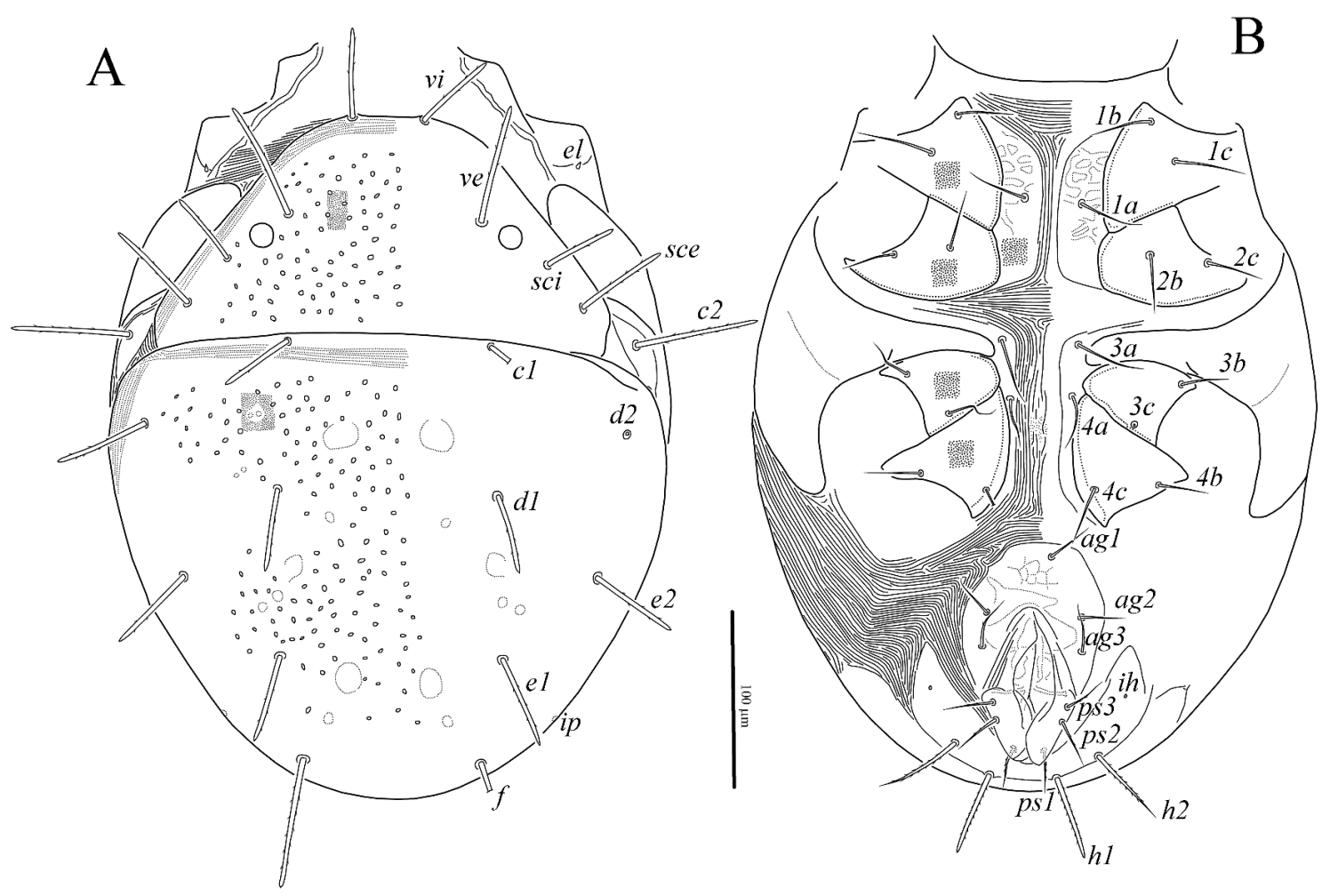

Fig. 14. Postumius mikhailovi sp.n., female (holotype): A-idiosomal dorsum, B-idiosomal venter.

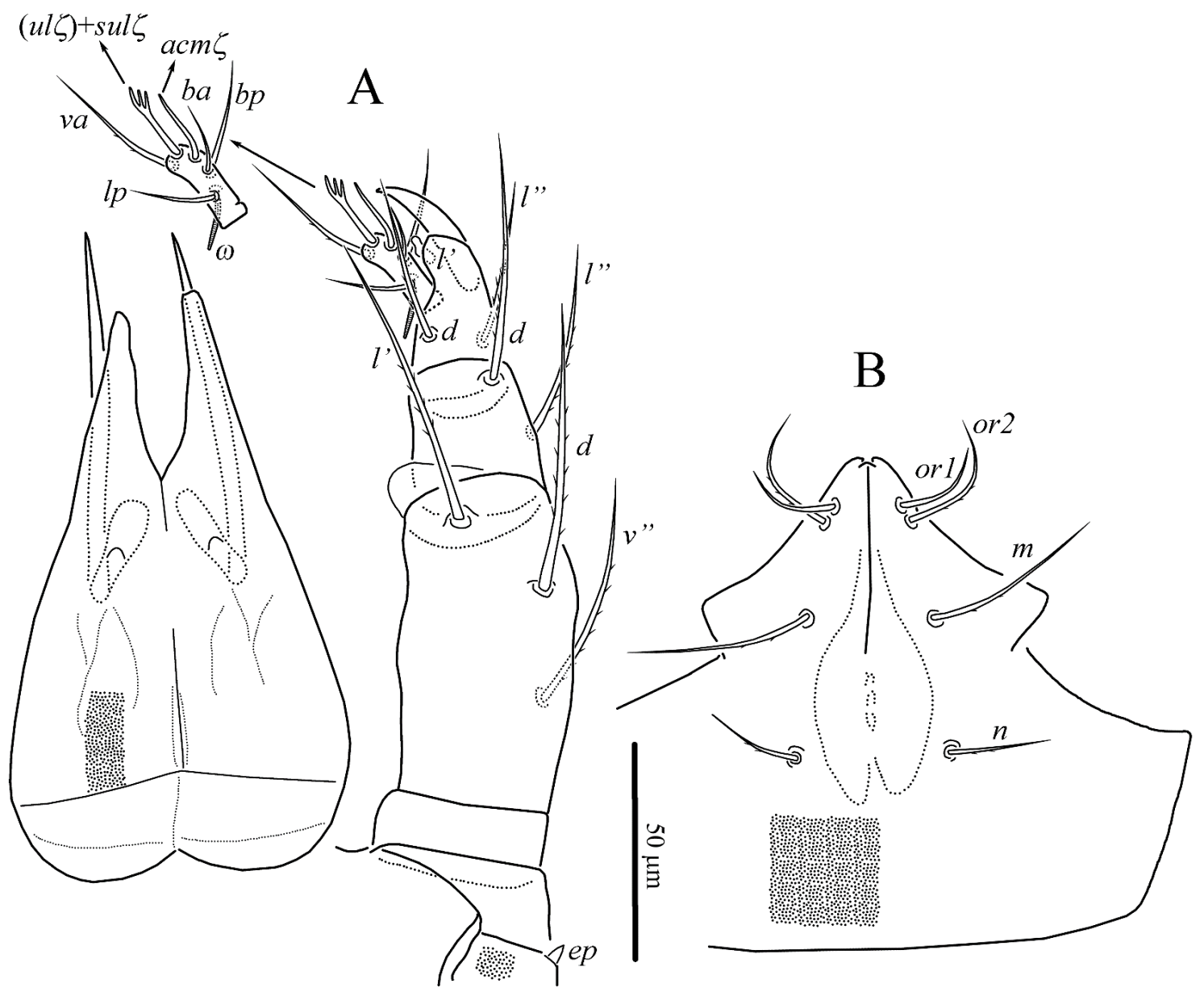

Fig. 15. Postumius mikhailovi sp.n., female (holotype): A—gnathosoma, dorsal aspect; B—subcapitulum. 


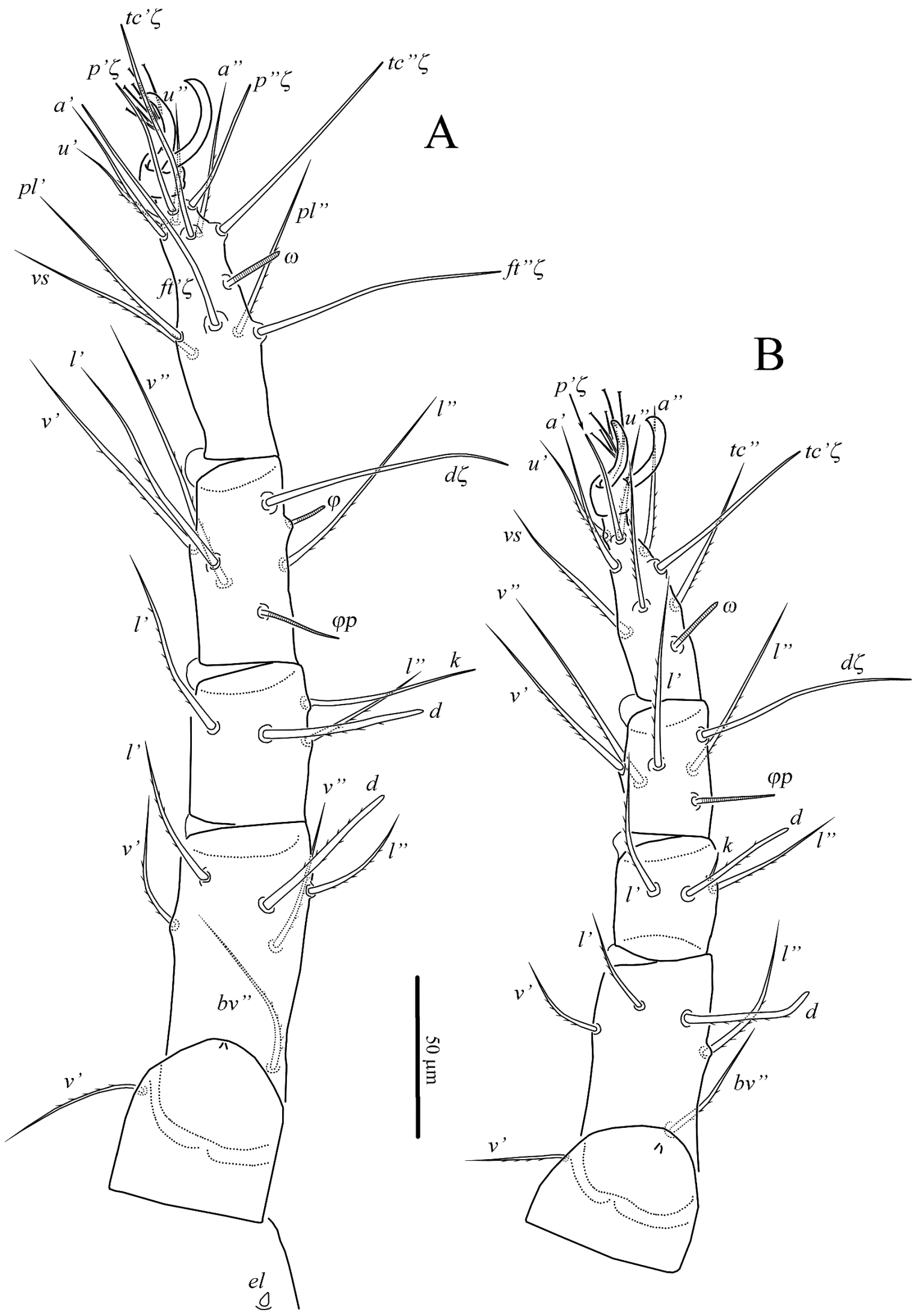

Fig. 16. Postumius mikhailovi sp.n., female (holotype): A—right leg I, dorsal aspect; B—right leg II, dorsal aspect.

(Fig. 7E); dorsal idiosomal shields without dimples (only with tiny puncta). P. tectus
- Setae $c 2$ located on small platelet (Fig. 20F); humeral shields with not so deep depression; dor- 


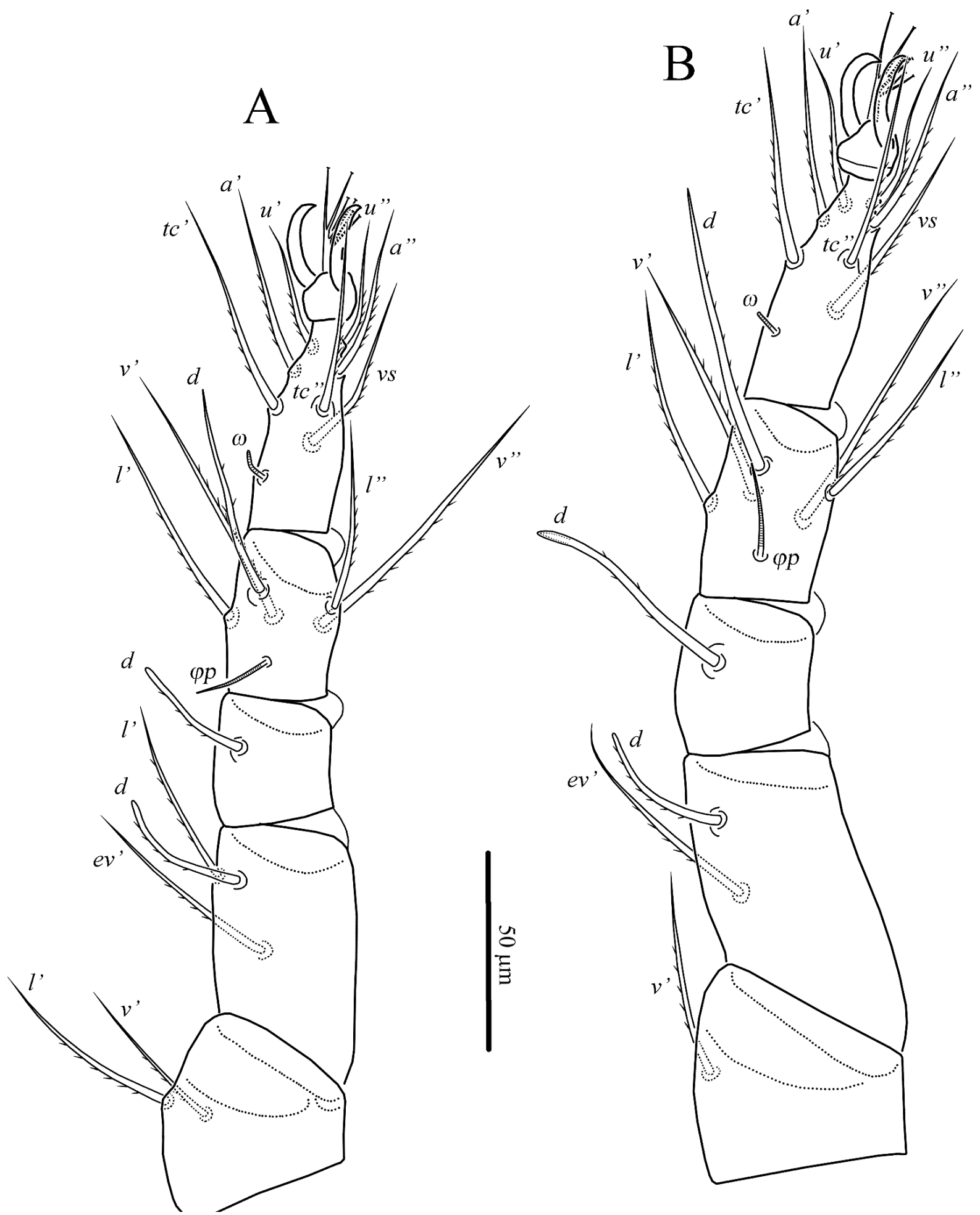

Fig. 17. Postumius mikhailovi sp.n., female (holotype): A—right leg III, dorsal aspect; B—right leg IV, dorsal aspect.

sal idiosomal shields with dimples

P. mikhailovi sp.n.

\section{ACKNOWLEDGEMENTS}

The present research was supported by the Russian Science Foundation, grant № 20-64-47015. 
A revision of Postumius (Acari: Prostigmata: Stigmaeidae)

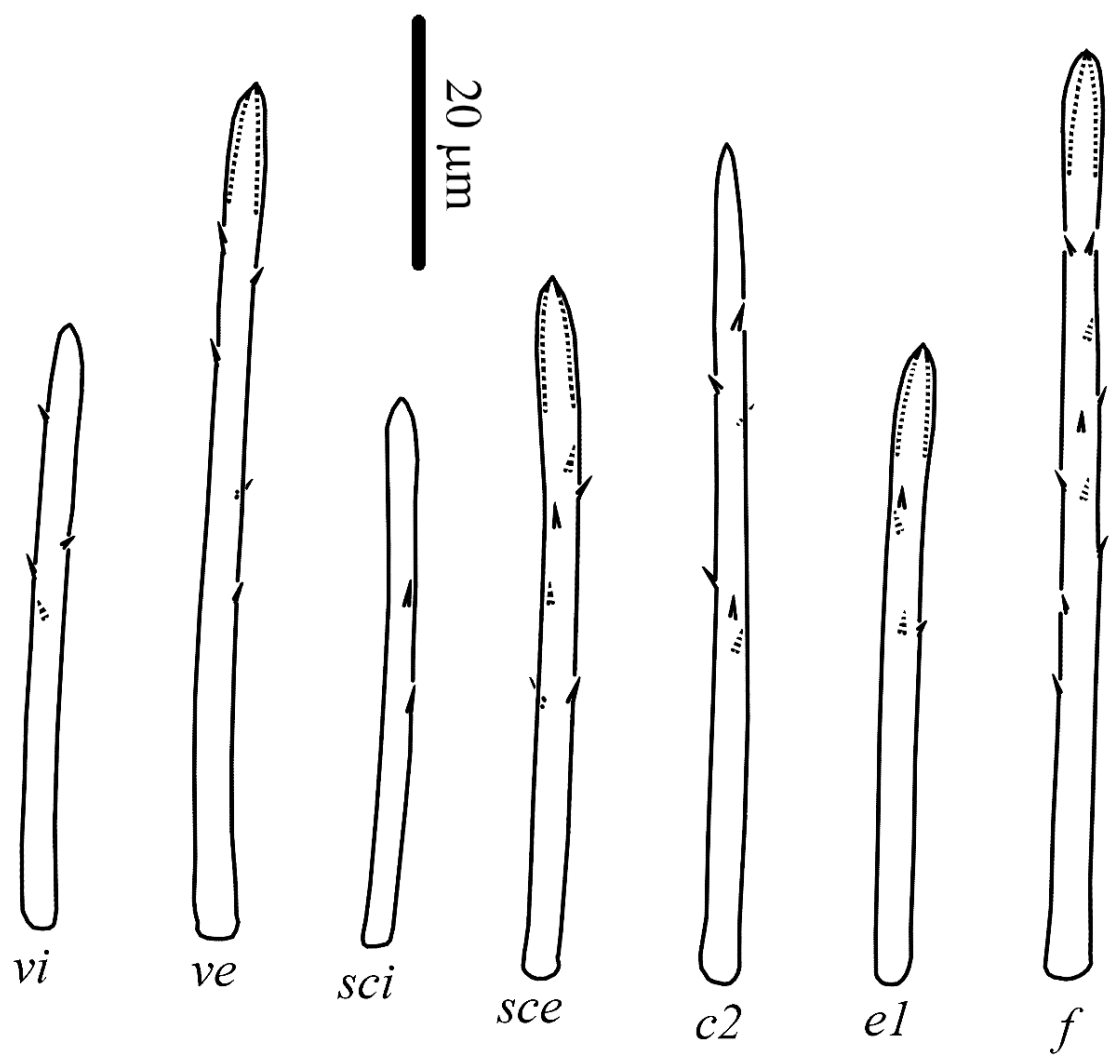

Fig. 18. Postumius mikhailovi sp.n., female (holotype): dorsal idiosomal setae.

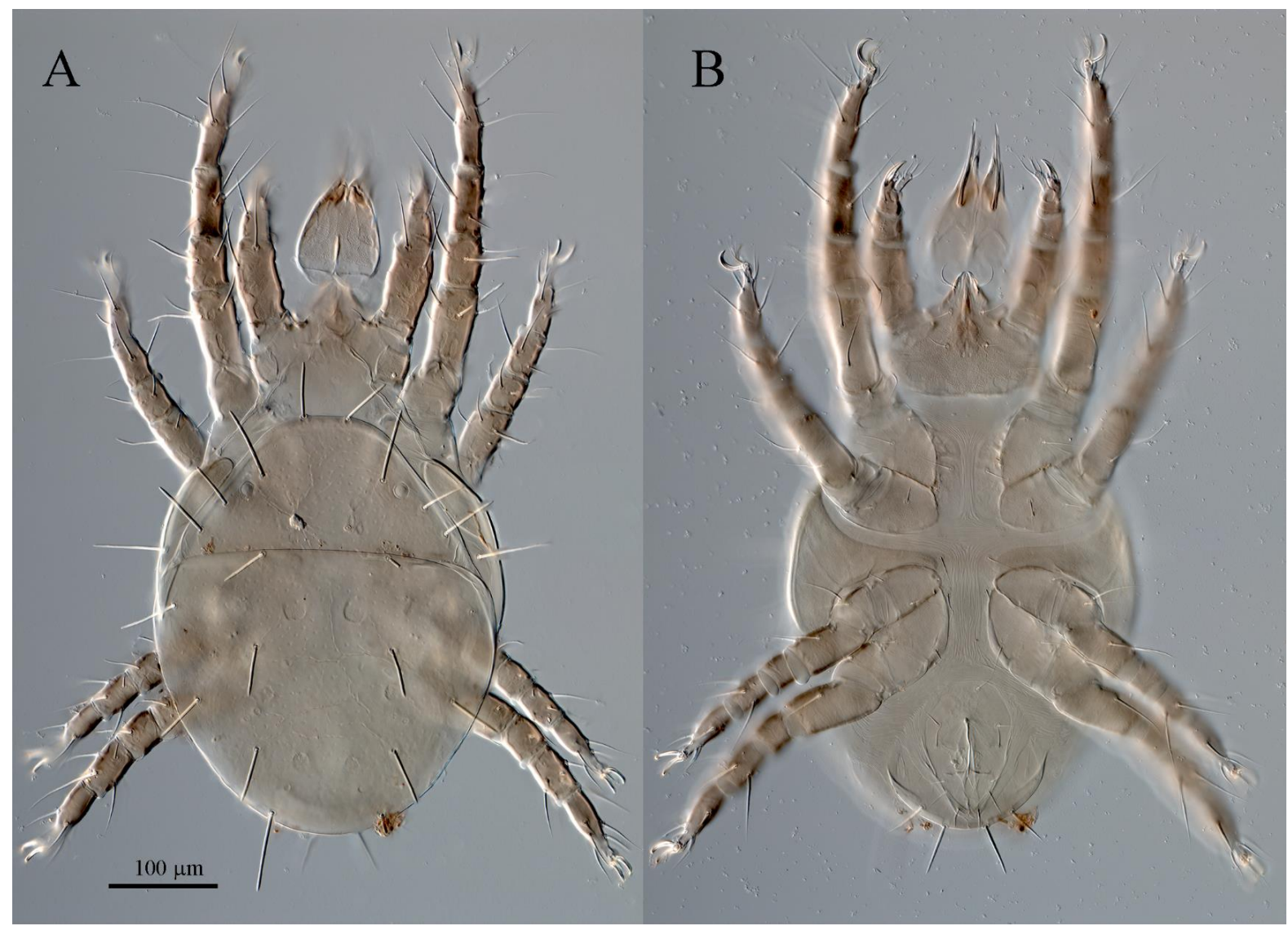

Fig. 19. DIC micrographs of Postumius mikhailovi sp.n., female (holotype): A—general view dorsally, B—general view ventrally. 


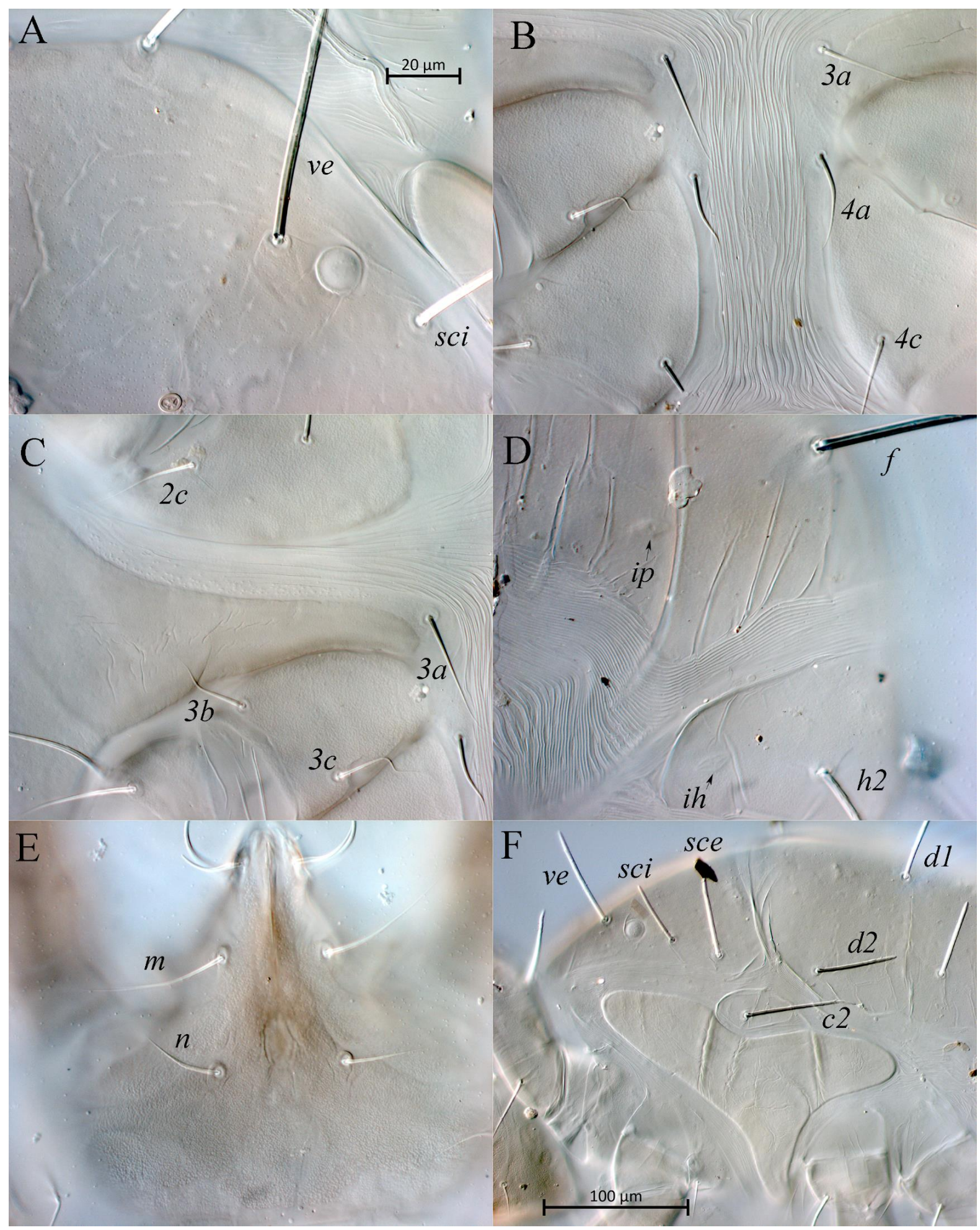

Fig. 20. DIC micrographs of Postumius mikhailovi sp.n., female (A-C, E-holotype, D, F-paratype): A-prodorsal shield; B-striation between coxal fields IV; C-metapodosomal venter showing fusion of endopodal plate of legs III and IV with humeral plate; D — opisthosoma, lateral aspect; E—-subcapitulum; F-anterior half of idiosoma, lateral aspect.

\section{REFERENCES}

Beron, P. 2020. Acarorum Catalogus VII: Trombidiformes, Prostigmata, Raphignathoidea (Fam. Barbutiidae, Caligonellidae, Camerobiidae, Cryp- tognathidae, Dasythyreidae, Dytiscacaridae, Eupalopsellidae, Homocaligidae, Mecognathidae, Raphignathidae, Stigmaeidae, Xenocaligonellididae). Pensoft, National Museum of Natural His- 
tory, Sofia, Bulgarian Academy of Sciences, Sofia. $306 \mathrm{pp}$.

Fan, Q.-H., Flechtmann, C.H.W. and De Moraes, G.J. 2016. Annotated catalogue of Stigmaeidae (Acari: Prostigmata), with a pictorial key to genera. Zootaxa, 4176: 1-199. DOI: 10.11646/zootaxa.4176.1.1

Fan, Q.-H., Flechtmann, C.H.W. and De Moraes, G.J. 2019. Emendations and updates to "Annotated catalogue of Stigmaeidae (Acari: Prostigmata), with a pictorial key to genera". Zootaxa, 4647 (1): 88-103. DOI: 10.11646/zootaxa.4647.1.9

Gerson, U., Smiley, R.L. and Ochoa, R. 2003. Mites (Acari) for Pest Control. Blackwell Science. 540 pp.

Grandjean, F. 1939. Les segments postlarvaires de l'hysterosoma chez les oribates (Acariens). Bulletin de la Société Zoologique de France, 64: 273-284.

Grandjean, F. 1944. Observations sur les Acariens de la famille des Stigmaeidae. Archives des Sciences Physiques et Naturelles, 26: 103-131.

Grandjean, F. 1946. Au sujet de l'organe de Claparède, des eupathides multiples et des taenidies mandibulaires chez les Acariens actinochitineux. $\mathrm{Ar}$ - chives des Sciences Physiques et Naturelles, 28: 63-87.

Kapaxidi, E.V. and Papadoulis, G.Th. 1999. New records of stigmaeid mites from Greece with description of a new species (Acari: Stigmaeidae). International Journal of Acarology, 25(2): 141-144. DOI: $10.1080 / 01647959908683625$

Kethley, J.B. 1990. Acarina: Prostigmata (Actinedida). In: D.L. Dindal (Ed.). Soil Biology Guide. Wiley, New York, pp. 667-756.

Khaustov, A.A. 2021. A new species and a new record of Stigmaeus (Acari: Prostigmata: Stigmaeidae) from Western Siberia, Russia. International Journal of Acarology, 47(3): 248-261. DOI: 10.1080/ 01647954.2021 .1892825

Kuznetsov, N.N. 1977. [A new genus and two new species of mites from the family Stigmaeidae (Acariformes)]. Zoologicheskiy Zhurnal, 56(2): 300-303. [In Russian]

Kuznetsov, N.N. 1978. [New records of raphignathoid mites (Raphignathoidea, Acariformes)]. Biologicheskie Nauki, 12: 49-54. [In Russian] 